\title{
Ownership Structure and Dividend Policy: Evidence from Thailand
}

\author{
Yordying Thanatawee
}

Correspondence: Yordying Thanatawee, Graduate School of Commerce, Burapha University, Chonburi, 20131, Thailand. Tel: 66-38-394900. E-mail: yordying@yahoo.com

Received: October 9, 2012 Accepted: November 5, 2012 Online Published: December 10, 2012

doi:10.5539/ijef.v5n1p121 URL: http://dx.doi.org/10.5539/ijef.v5n1p121

\begin{abstract}
This paper examines the relationship between ownership structure and dividend policy in Thailand in a sample of 1,927 observations over the period 2002-2010. The results show that Thai firms are more likely to pay dividends when they have higher ownership concentration or the largest shareholder is an institution and that firms pay higher dividends when the largest shareholder, especially an institution, holds more percentage of shares. It is also found that both the likelihood of paying dividends and the magnitude of dividend payouts increase (decrease) with higher institutional (individual) ownership, the findings mostly driven by the ownership of domestic investors.
\end{abstract}

Keywords: dividend policy, ownership structure, ownership concentration, Thailand

\section{Introduction}

Following Miller and Modigliani (1961) dividend irrelevance proposition, many researchers have attempted to explain why firms pay a substantial portion of their earnings as dividends if the amount of dividends paid to shareholders does not affect firm value. One of the most cited reasons for why firms pay dividends is the free cash flow hypothesis, which is based on the notion that there is a conflict of interest between managers and shareholders. Rather than act in shareholders' best interests, managers could allocate the firm's resources to benefit themselves (Jensen and Meckling, 1976). Managers' selfish behaviors can include undertaking unjustified mergers and acquisitions or lavish spending on perquisites. Hence, free cash flows can create agency problem because they may be used to fund negative NPV projects. To mitigate agency problem, Easterbrook (1984) and Jensen (1986) suggest that firms return free cash flows to shareholders by paying dividends. Easterbrook (1984) argues that dividends require managers to raise external funds more often and thus are more monitored by outsiders. According to Jensen (1986), dividends reduce the amount of cash that could be wasted by managers. Thus, dividends may be used as a mechanism to alleviate agency cost of free cash flows.

Based on the agency theories, recent studies have focused on examining the effects of governance standard and ownership structure on corporate dividend policy. For example, La Porta et al. (2000) find that firms in countries with low corporate governance and poor shareholder protection tend to pay low dividends and that firms with high ownership concentration tend to make higher dividend payments. Likewise, Mitton (2005) shows that, in emerging markets, firms with stronger corporate governance pay higher dividends. For US firms, Grinstein and Michaely (2005) document that institutions prefer dividend-paying firms to non-dividend-paying firms. However, institutions are not attracted to firms that pay high dividends and higher institutional holdings do not lead to higher dividends.

Examining the impact of foreign ownership on dividend policy of Japanese firms listed on the Tokyo Stock Exchange, Baba (2009) finds that a higher level of foreign ownership raises the probability of dividend payouts and dividend increases but lowers the probability of no dividend changes and dividend decreases. Similarly, Jeon et al. (2011) find that, for firms listed on the Korean stock market, higher dividends attract more foreign investors and the reverse is true when foreign investors have substantial shareholdings. Their results, however, are mostly driven by foreign institutions rather than domestic ones. Examining dividend policy of Japanese firms, Harada and Nguyen (2011) demonstrate that firms with higher ownership concentration pay lower dividends and are less likely to raise dividends when earnings increases or debt decreases. Likewise, Khan (2006) finds that ownership concentration is negatively related to dividends in the UK. The author also finds a positive relationship between institutional holding by insurance companies and dividends and a negative relationship between individual ownership and dividends. 
Although much empirical evidence on the relationship between ownership structure and dividends in the US and other developed countries has been documented, there is a scant literature on such issue from emerging markets, especially from Thailand. The Thai capital market offers an interesting setting in which to explore this issue for several reasons. First, according to La Porta et al. (2000), Thailand is characterized as a country with low shareholder protection and the ownership structure of Thai firms is highly concentrated. Second, it is documented that Thai firms are mostly owned and controlled by individuals, families, and related partners (see, e.g., Aivazian et al., 2003; Claessens et al., 2000; Wiwattanakantang, 2001). These characteristics can increase the agency costs of free cash flow and dividend payments are more likely to be used as a mechanism that helps mitigate agency problems. Further, Limpaphayom and Ngamwutikul (2004) document that, of the shares owned by the five largest shareholders of Thai firms, the majority is held by institutions, with a substantial average holding of 27 percent of total outstanding shares. Accordingly, this paper aims to investigate the roles of ownership structure on dividend policy of firms listed on the Stock Exchange of Thailand (SET).

The key contribution of this study is that it helps shed additional light on the inconclusive issues regarding the effects of ownership structure on dividend policy. In addition, it extensively examines the link between ownership structure and dividend policy, which is still unexplored in an emerging market like Thailand. To the best of the author's knowledge, there is no other study examining the relationship between ownership structure and dividend policy in Thailand as extensively as this paper. Particularly, this paper investigates the effects of the largest shareholder and ownership concentration on dividend policy of Thai firms. Large shareholders could enforce managers to pay dividends in order to alleviate the agency costs of free cash flow but they could influence managers to set low dividend policy to consume private benefits at the expenses of minority shareholders. The existing research provides mixed results on the effects of large shareholders on dividend payouts. For example, Gugler and Yurtoglu (2003) find a negative relation between the largest shareholder's ownership and divided payout ratio while Truong and Heaney (2007) document a convex relation, i.e., at low levels of shareholding, the relation between dividend payout ratio and the largest shareholder's ownership is negative but this relationship becomes positive as the levels of shareholding increase. The relationship between ownership concentration and dividend payouts is also inconclusive. It is found to be negative in Harada and Nguyen (2011), Khan (2006), and Renneboog and Trojanowski (2005) but insignificant in Grinstein and Michaely (2005).

This paper also focuses on examining the impact of institutional holding on dividend policy of Thai firms. Jensen's (1986) free cash flow hypothesis suggests that institutional investors can provide effective monitoring activities, thereby forcing managers to distribute free cash flows as dividends, or dividends could be used to compensate institutional investors for their monitoring activities (Shleifer and Vishny, 1986). Assuming that institutions can offer effective monitoring roles, the agency theories therefore predict a positive relationship between institutional holding and dividend payouts. A positive association between institutional ownership and dividend payout ratio is documented by Khan (2006), Moh'd et al. (1995), and Short et al. (2002) but a negative association is found by Renneboog and Trojanowski (2007).

The results from this study show that, compared to a firm with an individual as the largest shareholder, a firm with an institution as the largest shareholder is more likely to pay dividends and tends to pay higher dividends. In addition, ownership concentration is found to have a positive effect on a firm's likelihood to pay dividends. The evidence also indicates that higher institutional (individual) holdings are associated with higher (lower) likelihood that firms pay dividends and higher (lower) dividend payouts, the results are mostly driven by domestic rather than foreign ownership. Overall, the findings are broadly consistent with the agency theories proposed by Jensen (1986) and Shleifer and Vishny (1986).

The rest of this paper is organized as follows. Section 2 describes the sample and variable descriptions. Section 3 reports the empirical results, including descriptive statistics, Logit regressions, Tobit regressions, and a test for endogeneity of ownership. Section 4 concludes the paper.

\section{Data and Methodology}

\subsection{Model Specification}

To examine the relation between ownership structure and dividend policy, the following regression is estimated:

$$
D P R=\alpha+\beta_{1} * \text { OwnershipStructure }+\beta_{2} * \text { FirmCharacteristics }+\varepsilon
$$

where all variables are described in section 2.3 below.

The dividend policy of Thai firms is analyzed in two steps: (1) decision to pay or not to pay and (2) how much to pay. In the first step, the impact of ownership structure on firms' decisions whether to pay dividends is analyzed 
by performing binary Logit regressions where the dependent variable is a dummy variable equal to 1 for dividend-paying firms and 0 for no-paying firms. Then, the effect of ownership structure on the magnitude of dividend payouts is analyzed by estimating Tobit regressions where the dependent variable is dividend payout ratio (DPR), the ratio of dividends to net income. Given that a number of sample firms do not pay dividends and, accordingly, their dividend payout ratios are zero, Tobit regressions are utilized to eliminate biases from OLS estimates when the dependent variables are censored (see, e.g., Kim and Maddala, 1992; Wooldridge, 2010).

\subsection{Sample}

The ownership data was obtained from SETSMART (SET Market Analysis and Reporting Tool), the database of the Stock Exchange of Thailand (SET). The financial data was drawn from the database of Euromoney Institutional Investor (Plc.) via www.securities.com. The initial sample consists of 421 nonfinancial firms listed on the SET between 2002 and 2010. To calculate dividend payout ratio (DPR), which is equal to or higher than zero, firms reporting losses were removed from the initial sample. After eliminations of dividend-paying firms reporting negative earnings and firms with missing financial information, the final sample consists of 1,927 observations for 287 firms over the sample period.

\subsection{Variable Descriptions}

Following Adjaoud and Ben-Amar (2010), Farinha (2003), and Mitton (2004), the dependent variable is dividend payout ratio (DPR), the ratio of dividends over net income.

The main independent variables are ownership structure of Thai firms. TOP is the percent of shares held by the largest shareholder. Following Harada and Nguyen (2011) and Khan (2006), ownership concentration is measured by the percent of shares owned by the five largest shareholders (TOP5). I classify shareholdings of major shareholders (Note 1) disclosed by the Stock Exchange of Thailand (SET) into six categories as follows: INST is the percent of shares held by institutional investors (banks, financial institutions, insurance companies, funds, and unit trusts); DINST is the percent of shares held by domestic institutions; FINST is the percent of shares held by foreign institutions; INDV is the percent of shares held by individual investors; DINDV is the percent of shares held by domestic individuals; FINDV is the percent of shares held by foreign individuals; and FOREIGN is the percent of shares held by foreign institutional and individual investors.

In regression analysis, six firm characteristics are used as control variables. Industry dummies and year dummies are also included to account for industry-specific effects on dividend policy and unobserved economic variables, respectively. Return on assets (ROA), the ratio of operating income to total assets, is used to control for firm's profitability. Firms with higher profitability tend to pay higher dividends than firms with lower profitability. Therefore, a positive relationship between ROA and dividends is predicted.

Following Adjaoud and Ben-Amar (2010) and Baba (2009), free cash flow (FCF) is estimated by cash flows from operations. If dividends are used to mitigate agency problems, firms with higher free cash flows should pay more dividends. On the other hand, if managers expropriate shareholders, the results might indicate a negative relationship between free cash flows and dividends.

Firm size (SIZE) is the logarithm of total assets. Compared with smaller firms, larger firms tends to be more mature, have higher free cash flows, and are more likely to pay higher dividends. Thus, a positive relationship between firm size and dividends is expected.

Market-to-book ratio (MTB) is calculated as market value of equity divided by book value of equity. Following Fama and French (2001), market-to-book ratio is used as a proxy for future investment opportunities. A negative relationship between growth and dividends is expected because firms with higher growth opportunities are more likely to retain cash for future investments.

Leverage (LEV) is total debt divided by book value of total assets. Since firms with higher debt are more likely to be financially constrained and should be less able to pay dividends, a negative relationship between leverage and dividend payments is expected accordingly.

According to DeAngelo, DeAngelo and Stulz (2006) and Denis and Osobov (2008), the ratio of retained earnings to book value of equity has a significant positive relationship with corporate dividend policy in many developed countries. Thus, the ratio of retained earnings to book value of equity (RETE) is used to control for life-cycle of firms and it is predicted to have a positive relationship with dividend payouts in Thailand.

Finally, firm age (AGE), the logarithm of firm age since incorporation, is used as an instrumental variable in the tests for endogeneity problems.

The definitions of variables are provided in Table 1. 
Table 1. Definitions of variables

\begin{tabular}{ll}
\hline Variables & Definitions \\
\hline $\begin{array}{l}\text { Dependent variable } \\
\text { Dividend payout ratio }\end{array}$ & Dividends/net income \\
Ownership variables & \\
TOP & Percent of shares held by the largest shareholder \\
TOP5 & Percent of shares held by the five largest shareholders \\
INST & Percent of shares held by institutional shareholders \\
DINST & Percent of shares held by domestic institutional shareholders \\
FINST & Percent of shares held by foreign institutional shareholders \\
INDV & Percent of shares held by individual shareholders \\
DINDV & Percent of shares held by domestic individual shareholders \\
FINDV & Percent of shares held by foreign individual shareholders \\
FOREIGN & Percent of shares held by foreign shareholders \\
& \\
Firm characteristics & \\
Return on assets (ROA) & Operating income/total assets \\
Free cash flow (FCF) & Cash flows from operations/total assets \\
Firm size (SIZE) & The logarithm of total assets \\
Market-to-book ratio (MTB) & Market value of equity/book value of equity \\
Leverage (LEV) & Total debt/total assets \\
Retained earnings to equity (RETE) & Retained earnings/book value of equity \\
Firm age (AGE) & The logarithm of firm age since incorporation \\
\hline
\end{tabular}

\section{Empirical Results}

\subsection{Descriptive Statistics}

Table 2 reports ownership structure of the sample firms over the period 2002-2010. Overall, the ownership structure of Thai firms had been stable over the sample period, despite a slight increase in individual ownership due to domestic individual ownership and a small decline in institutional ownership due to foreign institutional ownership. As indicated by La Porta et al. (2000) that the ownership structure in Thailand is highly concentrated, the figures show that the average shareholding is 56.94 percent for the top five shareholders. The average ownership figure of the top five shareholders reported here is similar to 56.39 percent documented by Limpaphayom and Ngamwutikul (2004) during 1990-1994, suggesting a pattern of high ownership concentration in Thailand over time, but is much higher than 25 percent reported in Demsetz and Lehn (1985) for US firms and 32.94 percent reported in Harada and Nguyen (2011) for Japanese firms. Of the total shares held by major shareholders, institutional investors (INST) hold a larger proportion (43.46 percent) than individual investors (INDV). However, domestic individual investors (DINDV) hold the largest proportion of shares (35.47 percent) among the four categories of ownership (i.e., DINST, FINST, DINDV, and FINDV).

Table 2. Ownership structure of the sample firms

\begin{tabular}{lrrrrrrrrrr}
\hline Year & 2002 & 2003 & 2004 & 2005 & 2006 & 2007 & 2008 & 2009 & 2010 & Average \\
Obs. & 145 & \multicolumn{1}{c}{162} & \multicolumn{1}{c}{191} & \multicolumn{1}{c}{217} & \multicolumn{1}{c}{241} & \multicolumn{1}{c}{237} & \multicolumn{1}{c}{236} & \multicolumn{1}{c}{246} & \multicolumn{1}{c}{252} & 1,927 \\
\hline TOP & 26.35 & 26.51 & 27.66 & 28.52 & 29.32 & 28.89 & 28.89 & 28.07 & 28.49 & 28.23 \\
TOPINST & 0.41 & 0.51 & 0.48 & 0.47 & 0.50 & 0.49 & 0.47 & 0.46 & 0.48 & 0.48 \\
TOP5 & 55.80 & 55.78 & 55.93 & 56.29 & 58.43 & 57.42 & 57.55 & 57.16 & 57.03 & 56.94 \\
INST & 47.06 & 47.47 & 44.56 & 43.08 & 43.71 & 42.59 & 42.68 & 42.01 & 41.00 & 43.46 \\
INDV & 34.47 & 33.49 & 34.10 & 35.91 & 37.33 & 37.93 & 38.26 & 37.68 & 38.38 & 36.68 \\
DINST & 29.73 & 32.82 & 30.29 & 29.67 & 29.27 & 28.30 & 28.32 & 29.09 & 29.07 & 29.47 \\
DINDV & 33.06 & 32.14 & 32.75 & 34.65 & 36.15 & 37.08 & 36.84 & 36.46 & 37.38 & 35.47 \\
FINST & 17.33 & 14.65 & 14.27 & 13.41 & 14.45 & 14.28 & 14.35 & 12.92 & 11.92 & 13.99 \\
FINDV & 1.41 & 1.36 & 1.35 & 1.26 & 1.18 & 0.85 & 1.41 & 1.22 & 1.00 & 1.21 \\
FOREIGN & 18.75 & 16.01 & 15.62 & 14.67 & 15.62 & 15.14 & 15.77 & 14.14 & 12.92 & 15.20 \\
\hline
\end{tabular}


Table 3 shows the descriptive statistics for the sample firms. For dividend-paying firms, the average dividend payout ratio is 46.9 percent, which is significantly higher than 33.5 percent reported in Adjaoud and Ben-Amar (2010) for Canadian firms and 32.80 percent reported in Harada and Nguyen (2011) for Japanese firms. The results indicate that, except for foreign individual ownership (FINDV), the average ownership variables of dividend-paying firms are significantly different from those of no-paying firms. Particularly, dividend-paying firms have higher ownership concentration (TOP5), institutional ownership (INST), domestic institutional ownership (DINST), foreign institutional ownership (FINST), and foreign ownership (FOREIGN) but lower individual ownership (INDV) and domestic individual ownership (DINDV). However, firm age (AGE) is not significantly different between dividend-paying and non-paying firms.

Table 3. Descriptive statistics of the sample firms

\begin{tabular}{|c|c|c|c|c|c|c|c|c|}
\hline \multicolumn{4}{|c|}{ Paying firms $(n=1,382)$} & \multicolumn{3}{|c|}{ Non-paying firms $(n=545)$} & \multirow[b]{2}{*}{ Mean Diff. } & \multirow[b]{2}{*}{ t-statistic } \\
\hline Variable & Mean & Median & $\mathrm{SD}$ & Mean & Median & SD & & \\
\hline DPR & 0.469 & 0.447 & 0.234 & & & & & \\
\hline TOP & 28.74 & 24.42 & 15.59 & 26.77 & 23.61 & 15.82 & 2.024 & $2.542 * *$ \\
\hline TOPINST & 0.50 & 0.50 & 0.50 & 0.42 & 0.00 & 0.49 & 0.083 & $3.283 * *$ \\
\hline TOP5 & 57.64 & 57.10 & 15.36 & 54.95 & 56.24 & 17.66 & 2.769 & $3.197 * *$ \\
\hline INST & 46.72 & 48.82 & 27.16 & 35.24 & 28.87 & 26.58 & 11.392 & $8.296^{* *}$ \\
\hline INDV & 34.53 & 30.67 & 26.29 & 42.00 & 41.06 & 27.25 & -7.374 & $-5.455 * *$ \\
\hline DINST & 31.69 & 31.52 & 23.23 & 23.84 & 16.91 & 21.31 & 7.798 & $7.019 * *$ \\
\hline DINDV & 33.43 & 30.03 & 26.08 & 40.55 & 39.38 & 26.92 & -7.035 & $-5.251 * *$ \\
\hline FINST & 15.03 & 8.83 & 18.18 & 11.40 & 2.33 & 16.97 & 3.595 & $3.967 * *$ \\
\hline FINDV & 1.10 & 0.00 & 4.28 & 1.45 & 0.00 & 4.43 & -0.339 & -1.523 \\
\hline FOREIGN & 16.13 & 9.75 & 18.51 & 12.85 & 3.94 & 17.36 & 3.255 & $3.525^{* *}$ \\
\hline ROA & 0.111 & 0.096 & 0.072 & -0.012 & 0.011 & 0.109 & 0.124 & $24.203 * *$ \\
\hline FCF & 0.106 & 0.104 & 0.109 & 0.035 & 0.041 & 0.128 & 0.071 & $12.264 * *$ \\
\hline SIZE & 15.326 & 15.136 & 1.450 & 14.660 & 14.473 & 1.204 & 0.664 & $10.240 * *$ \\
\hline MTB & 1.518 & 1.162 & 1.206 & 1.211 & 0.764 & 1.361 & 0.306 & $4.808^{* *}$ \\
\hline LEV & 0.392 & 0.399 & 0.192 & 0.525 & 0.548 & 0.225 & -0.133 & $-12.129 * *$ \\
\hline RETE & 0.407 & 0.415 & 0.297 & -0.876 & 0.000 & 4.237 & 1.281 & $7.009 * *$ \\
\hline AGE & 1.3846 & 1.3979 & 0.2264 & 1.3808 & 1.3979 & 0.2185 & 0.0038 & 0.346 \\
\hline
\end{tabular}

$* *, *$ denote statistically significant at the $1 \%$ and $5 \%$ levels respectively.

\subsection{Multivariate Analysis}

In this section, I start by examining the influence of ownership structure on firm's decision whether to pay dividends. The results from Logit regressions in Table 4 show that, among control variables, ROA, SIZE, and RETE are significant determinants of firms' dividend payout decisions and their coefficients are positive, suggesting that firms with higher profitability, larger size, and more retained earnings are more likely to pay dividends. These results are in line with DeAngelo et al. (2006), Denis and Osobov (2008), and Fama and French (2001). 
Table 4. Logit analysis of firm's decision whether to pay dividends

\begin{tabular}{|c|c|c|c|c|c|c|c|}
\hline Variable & Model 1 & Model 2 & Model 3 & Model 4 & Model 5 & Model 6 & Model 7 \\
\hline \multirow[t]{2}{*}{ Intercept } & $-6.106^{* *}$ & $-6.836^{* *}$ & $-4.540 * *$ & $-5.261 * *$ & $-3.714 * *$ & $-3.708 * *$ & $-6.113 * *$ \\
\hline & (36.068) & (41.985) & (18.968) & $(23.272)$ & $(10.057)$ & $(10.026)$ & $(34.468)$ \\
\hline \multirow{2}{*}{$\mathrm{D} \cap A$} & $26.262 * *$ & $26.816^{* *}$ & $26.327 * *$ & $26.385^{* *}$ & $26.137 * *$ & $26.294 * *$ & $26.253 * *$ \\
\hline & (164.893) & $(168.952)$ & $(167.751)$ & $(166.525)$ & (165.967) & $(165.457)$ & $(166.766)$ \\
\hline \multirow[t]{2}{*}{ FCF } & -1.466 & -1.375 & -1.613 & -1.658 & -1.601 & -1.630 & -1.321 \\
\hline & (3.093) & $(2.712)$ & (3.692) & (3.847) & (3.659) & (3.779) & $(2.526)$ \\
\hline \multirow[t]{2}{*}{ SIZE } & $0.310^{* *}$ & $0.335^{* *}$ & $0.192 * *$ & $0.248^{* *}$ & $0.207 * *$ & $0.206^{* *}$ & $0.338 * *$ \\
\hline & (20.833) & (24.831) & (6.811) & (10.321) & $(7.592)$ & $(7.502)$ & $(21.668)$ \\
\hline \multirow[t]{2}{*}{ MTB } & -0.050 & -0.072 & -0.059 & -0.047 & -0.015 & -0.019 & -0.045 \\
\hline & $(0.305)$ & $(0.645)$ & $(0.435)$ & $(0.269)$ & $(0.026)$ & $(0.043)$ & $(0.252)$ \\
\hline \multirow[t]{2}{*}{ LEV } & -0.373 & -0.269 & -0.315 & -0.406 & -0.362 & -0.332 & -0.426 \\
\hline & $(0.684)$ & $(0.356)$ & $(0.489)$ & $(0.811)$ & $(0.666)$ & $(0.554)$ & $(0.893)$ \\
\hline \multirow[t]{2}{*}{ RETE } & $1.910 * *$ & $1.842 * *$ & $1.948 * *$ & $2.014 * *$ & $1.972 * *$ & $1.972 * *$ & $1.875^{* *}$ \\
\hline & (63.783) & $(60.305)$ & $(66.212)$ & $(68.856)$ & $(66.156)$ & $(66.202)$ & $(61.881)$ \\
\hline \multirow[t]{2}{*}{ TOP } & 0.007 & & & & & & \\
\hline & (2.033) & & & & & & \\
\hline \multirow[t]{2}{*}{ TOPINST } & $0.392 *$ & & & & & & \\
\hline & $(6.350)$ & & & & & & \\
\hline \multirow[t]{3}{*}{ TOP5 } & & $0.011^{*}$ & & & & & \\
\hline & & (5.819) & & & & & \\
\hline & & (5.819) & & & & & \\
\hline \multirow[t]{2}{*}{ INST } & & & $0.015^{* *}$ & & & & \\
\hline & & & (21.377) & & & & \\
\hline \multirow[t]{3}{*}{ DINST } & & & & $0.021^{* *}$ & & & \\
\hline & & & & (30.424) & & & \\
\hline & & & & (30.424) & & & \\
\hline \multirow[t]{2}{*}{ FINST } & & & & 0.003 & & & \\
\hline & & & & $(0.285)$ & & & \\
\hline \multirow[t]{2}{*}{ INDV } & & & & & $-0.012 * *$ & & \\
\hline & & & & & (13.899) & & \\
\hline \multirow[t]{2}{*}{ DINDV } & & & & & & $-0.012 * *$ & \\
\hline & & & & & & (13.899) & \\
\hline \multirow[t]{2}{*}{ FINDV } & & & & & & -0.001 & \\
\hline & & & & & & $(0.006)$ & \\
\hline \multirow[t]{2}{*}{ FOREIGN } & & & & & & & -0.001 \\
\hline & & & & & & & $(0.096)$ \\
\hline Year dummies & yes & yes & yes & yes & yes & yes & yes \\
\hline Industry dummies & yes & yes & yes & yes & yes & yes & yes \\
\hline Total obs. & 1,927 & 1,927 & 1,927 & 1,927 & 1,927 & 1,927 & 1,927 \\
\hline Nagelkerke $\mathrm{R}^{2}$ & $63.2 \%$ & $63.0 \%$ & $63.7 \%$ & $64.1 \%$ & $63.4 \%$ & $63.4 \%$ & $62.8 \%$ \\
\hline
\end{tabular}

Dependent variable is a dummy variable equal to 1 for dividend-paying firms and 0 for no-paying firms. The values reported in parentheses are Wald statistics. **, * denote statistically significant at the $1 \%$ and $5 \%$ levels respectively.

Model 1 indicates that the ownership of the largest shareholder (TOP) has no effect on a firm's decision whether to pay dividends. However, as indicated by a significantly positive coefficient on TOPINST, the identity of the largest shareholder appears to be associated with a firm's dividend decision. Essentially, compared with firms having an individual as the largest shareholder, firms with an institutional investor as the largest shareholder are more likely to pay dividends. This finding is consistent with Truong and Heaney's (2007) evidence showing that a firm is more likely to pay dividends when there is a financial institution as the largest shareholder.

In Model 2, the coefficient of TOP5 is positive and significant, indicating that firms with higher ownership concentration are more likely to pay dividends. This finding implies that large shareholders use dividends to constrain managerial opportunism, consistent with Shleifer and Vishny's (1986) argument that ownership concentration is a condition for large shareholders to provide monitoring roles. It is also found in Model 3 and 
Model 4 that the coefficients on INST and DINST are positive and significant. These findings suggest that as institutions, especially domestic ones, emerge as a major investor group, they play a key role in sponsoring a firm's dividend payouts. This is consistent with Short et al.'s (2002) evidence showing a positive association between institutional ownership and dividend payout ratio in the UK.

Model 5 and Model 6 of Table 3 reveal that the coefficients on INDV and DINDV are negative and significant, suggesting that powerful individual shareholders, especially domestic ones, appear to expropriate minority shareholders by lowering the likelihood that firms pay dividends. This is broadly consistent with Gugler (2003) evidence showing that, for Austrian firms, family-controlled firms are more likely to cut dividends than state-controlled firms. Further, as shown in Model 7, foreign ownership has no significant influence on a firm's decision whether to pay dividends.

Then, I proceed to investigate the influence of ownership structure on the amount of dividend payouts. The results from Tobit estimations in Table 5 generally reveal that coefficients on ROA, MTB, RETE and SIZE are positive and significant, while those on LEV are significantly negative. These findings suggest that firms with higher profitability, higher growth opportunities, more retained earnings, and larger size, pay higher dividends whereas firms with more debt pay lower dividends. The positive effects of profitability and firm size, and a negative impact of debt on dividend payouts are generally supported by prior literature (e.g., Fama and French, 2002; Jensen et al., 1992). Consistent with DeAngelo et al. (2006), Denis and Osobov (2008), and Thanatawee (2011), the retained earnings to book value of equity is positively related to dividend payouts. However, a positive relationship between growth opportunities and dividend payouts contradicts the findings by Fama and French (2002) and Jensen et al. (1992).

Model 1 shows a positive and statistically significant coefficient for TOP, suggesting that the higher ownership of the largest shareholder, the higher the dividend payouts, a finding consistent with Truong and Heaney (2007). In addition, the coefficient on TOPINST is positive and statistically significant. This is an indication that firms having an institutional investor as the largest shareholder pay higher dividends than do firms having an individual investor as the largest shareholder. Although ownership concentration (TOP5) appears to have a positive influence on a firm's decision whether to pay dividends, it is insignificant determinant of dividend payouts as shown in Model 2 (Note 2).

Model 3 and Model 4 show that INST and DINST are positively significant determinants of dividend payout ratio in Thailand. A positive coefficient on INST suggests that firms pay higher dividends when institutional shareholding is high, a finding consistent with Khan (2006) and Short et al. (2002) but contrary to Renneboog and Trojanowski (2005). A positive coefficient on DINST but insignificant one on FINST indicates, however, that dividend payouts of Thai firms are positively driven by domestic institutions rather than by foreign institutions. This finding contradicts Jeon et al.'s (2011) evidence from Korea showing that dividend payouts are significantly driven by foreign institutional investors but not by domestic institutional investors.

As indicated in Model 5, the coefficient on INDV is significantly negative, indicating firms pay lower dividends when the individual shareholding is higher. A negative relationship between individual ownership and dividends is also found by Khan (2006). In addition, as indicated by Model 6, the coefficients on DINDV and FINDV are negative and statistically significant, showing that both categories of individual ownership, domestic and foreign ones, have negative impact on dividend payouts in Thailand. Consistent with Shleifer and Vishny's (1997) argument, these findings suggest that when individual investors emerge as major shareholders, they appear to extract private benefits not shared by minority shareholders by paying out lower amounts of dividends. Finally, Model 7 shows insignificant coefficient on FOREIGN, indicating that aggregate equity ownership by foreign investors has no significant impact on dividend payouts by Thai firms. 
Table 5. Tobit analysis of dividend payouts

\begin{tabular}{|c|c|c|c|c|c|c|c|}
\hline Variable & Model 1 & Model 2 & Model 3 & Model 4 & Model 5 & Model 6 & Model 7 \\
\hline Intercept & $\begin{array}{l}-0.0385 \\
(-0.4046)\end{array}$ & $\begin{array}{l}-0.0924 \\
(-0.9361)\end{array}$ & $\begin{array}{l}-0.1641 \\
(-1.3563)\end{array}$ & $\begin{array}{l}0.0599 \\
(0.6118)\end{array}$ & $\begin{array}{l}0.1784 \\
(1.5821)\end{array}$ & $\begin{array}{l}0.1730 \\
(1.5368)\end{array}$ & $\begin{array}{l}-0.0628 \\
(-0.6565)\end{array}$ \\
\hline ROA & $\begin{array}{l}1.3339 * * \\
(9.0693)\end{array}$ & $\begin{array}{l}1.3368 * * \\
(9.0472)\end{array}$ & $\begin{array}{l}1.3324 * * \\
(9.0066)\end{array}$ & $\begin{array}{l}1.3319^{* *} \\
(8.9864)\end{array}$ & $\begin{array}{l}1.3389^{* *} \\
(9.0753)\end{array}$ & $\begin{array}{l}1.3222 * * \\
(9.0189)\end{array}$ & $\begin{array}{l}1.3230 * * \\
(8.9233)\end{array}$ \\
\hline FCF & $\begin{array}{l}-0.1125 \\
(-1.2631)\end{array}$ & $\begin{array}{l}-0.1031 \\
(-1.1561)\end{array}$ & $\begin{array}{l}-0.0991 \\
(-1.1144)\end{array}$ & $\begin{array}{l}-0.1216 \\
(-1.3725)\end{array}$ & $\begin{array}{l}-0.1167 \\
(-1.3211)\end{array}$ & $\begin{array}{l}-0.1053 \\
(-1.1992)\end{array}$ & $\begin{array}{l}-0.0959 \\
(-1.0774)\end{array}$ \\
\hline SIZE & $\begin{array}{l}0.0080 \\
(1.3196)\end{array}$ & $\begin{array}{l}0.0119 * \\
(1.9724)\end{array}$ & $\begin{array}{l}0.0126^{* *} \\
(2.0919)\end{array}$ & $\begin{array}{l}0.0017 \\
(0.2599)\end{array}$ & $\begin{array}{l}-0.0004 \\
(-0.0557)\end{array}$ & $\begin{array}{l}-0.0000 \\
(-0.0052)\end{array}$ & $\begin{array}{l}0.0136^{*} \\
(2.1488)\end{array}$ \\
\hline MTB & $\begin{array}{l}0.0179 * \\
(2.3677)\end{array}$ & $\begin{array}{l}0.0176^{*} \\
(2.3244)\end{array}$ & $\begin{array}{l}0.0167^{*} \\
(2.1902)\end{array}$ & $\begin{array}{l}0.0184 * \\
(2.4311)\end{array}$ & $\begin{array}{l}0.0195 * * \\
(2.5922)\end{array}$ & $\begin{array}{l}0.0200 * * \\
(2.7152)\end{array}$ & $\begin{array}{l}0.0182 * \\
(2.3997)\end{array}$ \\
\hline LEV & $\begin{array}{l}-0.2152 * * \\
(-4.3724)\end{array}$ & $\begin{array}{l}-0.2150 * * \\
(-4.3531)\end{array}$ & $\begin{array}{l}-0.2141 * * \\
(-4.3158)\end{array}$ & $\begin{array}{l}-0.2133 * * \\
(-4.2857)\end{array}$ & $\begin{array}{l}-0.2101 * * \\
(-4.2226)\end{array}$ & $\begin{array}{l}-0.2141 * * \\
(-4.3145)\end{array}$ & $\begin{array}{l}-0.2246^{* *} \\
(-4.5064)\end{array}$ \\
\hline RETE & $\begin{array}{l}0.2708^{* *} \\
(7.6501)\end{array}$ & $\begin{array}{l}0.2699 * * \\
(7.5721)\end{array}$ & $\begin{array}{l}0.2678^{* *} \\
(7.5070)\end{array}$ & $\begin{array}{l}0.2754 * * \\
(7.7476)\end{array}$ & $\begin{array}{l}0.2752 * * \\
(7.8194)\end{array}$ & $\begin{array}{l}0.2762 * * \\
(7.8523)\end{array}$ & $\begin{array}{l}0.2724 * * \\
(7.4939)\end{array}$ \\
\hline TOP & $\begin{array}{l}0.0011^{*} \\
(2.2346)\end{array}$ & & & & & & \\
\hline TOPINST & $\begin{array}{l}0.0383 * \\
(2.4417)\end{array}$ & & & & & & \\
\hline TOP5 & & $\begin{array}{l}0.0080 \\
(1.5547)\end{array}$ & & & & & \\
\hline INST & & & $\begin{array}{l}0.0013 * * \\
(3.9847)\end{array}$ & & & & \\
\hline DINST & & & & $\begin{array}{l}0.0017 * * \\
(4.6177)\end{array}$ & & & \\
\hline FINST & & & & $\begin{array}{l}0.0005 \\
(0.9997)\end{array}$ & & & \\
\hline INDV & & & & & $\begin{array}{l}-0.0012 * * \\
(-3.4674)\end{array}$ & & \\
\hline DINDV & & & & & & $\begin{array}{l}-0.0011 * * \\
(-3.2149)\end{array}$ & \\
\hline FINDV & & & & & & $\begin{array}{l}-0.0049 * \\
(-2.3520)\end{array}$ & \\
\hline FOREIGN & & & & & & & $\begin{array}{l}-0.0003 \\
(-0.6998)\end{array}$ \\
\hline Year dummies & yes & yes & yes & yes & yes & yes & yes \\
\hline Industry dummies & yes & yes & yes & yes & yes & yes & yes \\
\hline Total obs. & 1,927 & 1,927 & 1,927 & 1,927 & 1,927 & 1,927 & 1,927 \\
\hline Left censored obs. & 545 & 545 & 545 & 545 & 545 & 545 & 545 \\
\hline Log likelihood & -696.9783 & -701.6586 & -694.5794 & -691.9577 & -696.2782 & -694.1024 & -702.6297 \\
\hline
\end{tabular}

Dependent variable is dividend payout ratio (DPR). The values reported in parentheses are Huber/White robust standard errors z-statistics. ${ }^{* *}, *$ denote statistically significant at the $1 \%$ and $5 \%$ levels respectively.

\subsection{Possible Endogeneity Test}

The results from Tobit regressions in prior section generally indicate that the association between dividend payout ratio and percentage of equity ownership is positive for institutional investors but negative for individual investors. However, such findings can be spurious in the existence of endogenous relationship between ownership structure and dividend policy. To test the endogeneity problem in a Tobit model, I employ Smith and Blundell's (1986) two-stage procedure as suggested by Wooldridge (2010). 
Table 6. A two-stage procedure test for endogeneity of ownership

\begin{tabular}{|c|c|c|c|c|c|c|}
\hline Dependent variable & $\begin{array}{l}\text { Model } 1 \\
\text { DINST } \\
\text { Stage } 1\end{array}$ & $\begin{array}{c}\text { Model } 2 \\
\text { DPR } \\
\text { Stage } 2\end{array}$ & $\begin{array}{l}\text { Model } 3 \\
\text { DINDV } \\
\text { Stage } 1\end{array}$ & $\begin{array}{l}\text { Model } 4 \\
\text { DPR } \\
\text { Stage } 2\end{array}$ & $\begin{array}{l}\text { Model } 5 \\
\text { FINDV } \\
\text { Stage } 1\end{array}$ & $\begin{array}{l}\text { Model } 6 \\
\text { DPR } \\
\text { Stage } 2\end{array}$ \\
\hline Intercept & $\begin{array}{l}-65.6545^{* *} \\
(-9.9058)\end{array}$ & $\begin{array}{l}-0.0463 \\
(-0.2676)\end{array}$ & $\begin{array}{l}198.3412^{* *} \\
(28.6516)\end{array}$ & $\begin{array}{l}-0.04735 \\
(-0.1069)\end{array}$ & $\begin{array}{l}7.7226^{* *} \\
(7.2872\end{array}$ & $\begin{array}{l}-0.0499 \\
(-0.4983)\end{array}$ \\
\hline ROA & $\begin{array}{l}5.3625 \\
(0.8511)\end{array}$ & $\begin{array}{l}1.3304 * * \\
(9.009)\end{array}$ & $\begin{array}{l}23.1793^{* *} \\
(3.1652)\end{array}$ & $\begin{array}{l}1.3128^{* *} \\
(8.0689)\end{array}$ & $\begin{array}{l}-4.7074 * * \\
(-2.8561)\end{array}$ & $\begin{array}{l}1.3256^{* *} \\
(8.7219)\end{array}$ \\
\hline FCF & $\begin{array}{l}11.2746^{*} \\
(2.4454)\end{array}$ & $\begin{array}{l}-0.0999 \\
(-1.0363)\end{array}$ & $\begin{array}{l}-15.3856^{* *} \\
(-2.6353)\end{array}$ & $\begin{array}{l}-0.0996 \\
(-1.0164)\end{array}$ & $\begin{array}{l}2.4657 * \\
(2.1499)\end{array}$ & $\begin{array}{l}-0.0949 \\
(-1.0426)\end{array}$ \\
\hline SIZE & $\begin{array}{l}4.5624 * * \\
(12.2216)\end{array}$ & $\begin{array}{l}0.0117 \\
(0.7967)\end{array}$ & $\begin{array}{l}-9.7685^{* *} \\
(-26.8695)\end{array}$ & $\begin{array}{l}0.0119 \\
(0.4890)\end{array}$ & $\begin{array}{l}-0.1955^{* *} \\
(-3.0403)\end{array}$ & $\begin{array}{l}0.0122 * \\
(1.9354)\end{array}$ \\
\hline MTB & $\begin{array}{l}-0.3112 \\
(-0.3112)\end{array}$ & $\begin{array}{l}0.0178 * \\
(2.3179)\end{array}$ & $\begin{array}{l}0.4027 \\
(0.7932)\end{array}$ & $\begin{array}{l}0.0186 * \\
(2.4299)\end{array}$ & $\begin{array}{l}0.3141 * \\
(2.1382)\end{array}$ & $\begin{array}{l}0.0175^{*} \\
(2.1065)\end{array}$ \\
\hline LEV & $\begin{array}{l}3.8913 \\
(1.3524)\end{array}$ & $\begin{array}{l}-0.2146^{* *} \\
(-4.2940)\end{array}$ & $\begin{array}{l}7.3717 * \\
(2.2542)\end{array}$ & $\begin{array}{l}-0.2200 * * \\
(-4.0404)\end{array}$ & $\begin{array}{l}-1.4325 * * \\
(-2.9008)\end{array}$ & $\begin{array}{l}-0.2197 * * \\
(-4.3281)\end{array}$ \\
\hline RETE & $\begin{array}{l}-0.2584 \\
(-0.7938)\end{array}$ & $\begin{array}{l}0.2766^{* *} \\
(7.7157)\end{array}$ & $\begin{array}{l}0.5245 \\
(1.6341)\end{array}$ & $\begin{array}{l}0.2743 * * \\
(7.7648)\end{array}$ & $\begin{array}{l}0.0606 \\
(1.8737)\end{array}$ & $\begin{array}{l}0.2730 * * \\
(7.6144)\end{array}$ \\
\hline DINST & & $\begin{array}{l}-0.0000 \\
(-0.0089)\end{array}$ & & & & \\
\hline DINDV & & & & $\begin{array}{l}0.0000 \\
(0.0137)\end{array}$ & & \\
\hline FINDV & & & & & & $\begin{array}{l}-0.0005 \\
(-0.0403)\end{array}$ \\
\hline AGE & $\begin{array}{l}11.5360^{* *} \\
(4.2237)\end{array}$ & & $\begin{array}{l}-14.1847 * * \\
(-5.8669)\end{array}$ & & $\begin{array}{l}-3.0496 * * \\
(-5.5975)\end{array}$ & \\
\hline VHAT & & $\begin{array}{l}0.0016 \\
(0.5395)\end{array}$ & & $\begin{array}{l}-0.0011 \\
(-0.4524)\end{array}$ & & $\begin{array}{l}-0.0041 \\
(-0.3556)\end{array}$ \\
\hline Year dummies & yes & yes & yes & yes & yes & yes \\
\hline Industry dummies & yes & yes & yes & yes & yes & yes \\
\hline Total obs. & 1,927 & 1,927 & 1,927 & 1,927 & 1,927 & 1,927 \\
\hline Adjusted $\mathrm{R}^{2}$ & $12.96 \%$ & & $28.33 \%$ & & $7.05 \%$ & \\
\hline Left censored obs. & & 545 & & 545 & & 545 \\
\hline Log likelihood & & -692.3263 & & -697.7223 & & -699.7628 \\
\hline
\end{tabular}

This table reports results of Smith and Blundell's (1986) two-stage procedure for endogeneity test in Tobit regression. Stage 1 is the OLS regression. Stage 2 is the Tobit regression. DPR is dividend payout ratio measured by dividends over net income. AGE is an instrumental variable, measured by logarithm of firm age since incorporation. The values reported in parentheses of OLS regressions are White robust standard errors z-statistics. VHAT are residuals obtained from stage 1 OLS regressions. The values reported in parentheses of stage 2 Tobit regressions are Huber/White robust standard errors t-statistics. $* *, *$ denote statistically significant at the $1 \%$ and $5 \%$ levels respectively.

Specifically, I test for the potential endogenous variables, LINST, DINDV, and FINDV, which are found to have significant relations with dividend payouts in the two-stage procedure as follows: First, I estimate the reduced form OLS regressions of LINST, DINDV, and FINDV on all exogenous variables (i.e., control variables) and an instrumental variable, AGE, which is firm age since the firm is incorporated (Note 3). Second, I estimate the Tobit regressions of DPR on exogenous variables, potential endogenous variables (LINDV, DINDV, and FINDV) and VHAT, the residuals from estimating the reduced form OLS of LINST, DINDV, and FINDV in stage 1. If the coefficient on VHAT is statistically significant, the variable tested is endogenous.

Model 1, Model 3, and Model 5 of Table 6 show the first stage OLS estimates of LINST, DINDV, and FINDV, respectively. Note that, the coefficients of AGE are highly significant at $1 \%$ level in all three Models, indicating that AGE is a strong instrumental variable (Note 4). Model 2, Model 4, and Model 6 show the second stage Tobit estimates of dividend payout ratio (DPR), controlling for firm characteristics and including VHAT as an additional explanatory variable, on LINDV, DINDV, and FINDV, respectively. The results reveal that coefficients of VHAT are not significant in all three Models, indicating that LINDV, DINDV, and FINDV are 
exogenous variables. Therefore, the findings of relationship between ownership structure and dividend policy in this study are not exposed to endogeneity problem.

\section{Conclusion}

This study investigates the impacts of ownership structure on dividend policy in Thailand over the period 2002-2010. The results show that Thai firms have highly concentrated ownership structure and are mostly owned by institutions. The dividend policy of Thai firms is analyzed in two steps: (1) decision to pay or not to pay and (2) how much to pay. The results reveal that, among controlled variables, profitability, firm size, and the ratio of retained earnings to book equity, have positive effects on a firm's decision whether to pay dividends and how much to pay dividends. In addition, the amount of dividend payouts is found be positively related to growth opportunities but negatively related to financial leverage. Free cash flow, however, is not found to have a significant relation with dividend policy of Thai firms.

The results also demonstrate that a firm with higher ownership concentration and an institution, compared with an individual, as the largest shareholder is more likely to pay dividends and that the largest shareholder's holding is positively related to dividend payouts. In addition, firms are more (less) likely to pay dividends and tend to pay higher (lower) dividends when they have higher institutional (individual) holding, the findings are mostly driven by domestic ownership rather than by foreign ownership. Consistent with agency theories (e.g., Jensen, 1986), the findings of this paper suggest that powerful individual shareholders expropriate minority shareholders by restraining dividend payouts while major institutional shareholders could provide effective monitoring roles and influence managers to pay more dividends.

\section{Acknowledgements}

The author is grateful to Graduate School of Commerce, Burapha University, for providing research grants to conduct this study.

\section{References}

Adjaoud, F., \& Ben-Amar, W. (2010). Corporate governance and dividend policy: Shareholders' protection or expropriation? Journal of Business Finance and Accounting, 37, 648-667. http://dx.doi.org/10.1111/j.1468-5957.2010.02192.x

Aivazian, V., Booth, L., \& Cleary, S. (2003). Dividend policy and the organization of capital markets. Journal of Multinational Financial Management, 13, 101-121. http://dx.doi.org/10.1016/S1042-444X(02)00038-5

Baba, N. (2009). Increased presence of foreign investors and dividend policy of Japanese firms. Pacific-Basin Finance Journal, 17, 163-174. http://dx.doi.org/10.1016/j.pacfin.2008.04.001

Claessens, S., Djankov, S., \& Lang, L. H. P. (2000). The separation of ownership and control in East Asian $\begin{array}{lllll}\text { corporations. Journal of Financial } & \text { Economics, } & 58, & \text { 81-112. }\end{array}$ http://dx.doi.org/10.1016/S0304-405X(00)00067-2

DeAngelo, H., DeAngelo, L., \& Stulz, R. M. (2006). Dividend policy and the earned/contributed capital mix: A test of the life-cycle theory. Journal of Financial Economics, 81, 227-254. http://dx.doi.org/10.1016/j.jfineco.2005.07.005

Demsetz, H., \& Lehn, K. (1985). The structure of corporate ownership: causes and consequences. Journal of Political Economy, 93, 1155-1177. http://dx.doi.org/10.1086/261354

Denis, D. J., \& Osobov, I. (2008). Why do firms pay dividends? International evidence on the determinants of dividend policy. Journal of Financial Economics, 89, 62-82. http://dx.doi.org/10.1016/j.jfineco.2007.06.006

Easterbrook, F. H. (1984). Two agency-cost explanations of dividends. American Economic Review, 74, 650-659.

Fama, F. E., \& French, K. R. (2001). Disappearing dividends: Changing firm characteristics or lower propensity to pay? Journal of Financial Economics, 60, 3-43. http://dx.doi.org/10.1016/S0304-405X(01)00038-1

Farinha, J. (2003). Dividend policy, corporate governance and the managerial entrenchment hypothesis: an empirical analysis. Journal of Business Finance and Accounting, 30, 1173-1209. http://dx.doi.org/10.1111/j.0306-686X.2003.05624.x

Grinstein, Y., \& Michaely, R. (2005). Institutional holdings and payout policy. Journal of Finance, 60, 1389-1426. http://dx.doi.org/10.1111/j.1540-6261.2005.00765.x

Gugler, K. (2003). Corporate governance, dividend payout policy, and the interrelation between dividends, R\&D, 
and capital investment. Journal of Banking and Finance, 27, 1297-1321. http://dx.doi.org/10.1016/S0378-4266(02)00258-3

Gugler, K., \& Yurtoglu, B. (2003). Corporate governance and dividend payout in Germany. European Economic Review, 47, 731-758. http://dx.doi.org/10.1016/S0014-2921(02)00291-X

Harada, K., \& Nguyen, P. (2011). Ownership concentration and dividend policy in Japan. Managerial Finance, 37, 362-379. http://dx.doi.org/10.1108/03074351111115313

Jensen, G., Solberg, D., \& Zorn, T. (1992). Simultaneous determination of insider ownership, debt, and dividend policies. Journal of Financial and Quantitative Analysis, 27, 247-263. http://dx.doi.org/10.2307/2331370

Jensen, M. (1986). Agency costs of free cash flow, corporate finance and takeovers. American Economic Review, 76, 323-329.

Jensen, M., \& Meckling, W. (1976). Theory of firm: Managerial behavior, agency costs and ownership structure. Journal of Financial Economics, 3, 305-360. http://dx.doi.org/10.1016/0304-405X(76)90026-X

Jeon, J. Q., Lee, C., \& Moffett, C. M. (2011). Effects of foreign ownership on payout policy: Evidence from the Korean market. Journal of Financial Markets, 14, 344-375. http://dx.doi.org/10.1016/j.finmar.2010.08.001

Khan, T. (2006). Company dividends and ownership structure: Evidence from UK panel data. The Economic Journal, 116, 172-189. http://dx.doi.org/10.1111/j.1468-0297.2006.01082.x

Kim, B. S., \& Maddala, G. S. (1992). Estimation and specification analysis models of dividends behavior based on censored panel data. Empirical Economics, 17, 111-124. http://dx.doi.org/10.1007/BF01192478

LaPorta, R., Lopez-de-Silanes, F., Shleifer, A., \& Vishny, R. W. (2000). Agency problems and dividend policies around the world. Journal of Finance, 55, 1-33. http://dx.doi.org/10.1111/0022-1082.00199

Limpaphayom, P., \& Ngamwuttikul, A. (2004). Ownership structure and post-issue operating performance of firms conducting seasoned equity offerings in Thailand. Journal of Economics and Finance, 28, 307-331. http://dx.doi.org/10.1007/BF02751735

Miller, M., \& Modigliani, F. (1961). Dividend policy, growth, and the valuation of shares. Journal of Business, 34, 411-433. http://dx.doi.org/10.1086/294442

Mitton, T. (2005). Corporate governance and dividend policy in emerging markets. Emerging Markets Review, 5 , 409-426. http://dx.doi.org/10.1016/j.ememar.2004.05.003

Moh'd, M., Perry, L., \& Rimbey, J. (1995). An investigation of the dynamic association beween agency theory and dividend policy. Financial Review, 30, 367-385. http://dx.doi.org/10.1111/j.1540-6288.1995.tb00837.x

Renneboog, L., \& Trojanowski, G. (2007). Control structures and payout policy. Managerial Finance, 33, 43-64. http://dx.doi.org/10.1108/03074350710715809

Shleifer, A., \& Vishny, R. (1986). Large shareholders and corporate control. Journal of Political Economy, 95, 461-488. http://dx.doi.org/10.1086/261385

Shleifer, A., \& Vishny, R. (1997). A survey on corporate governance. Journal of Finance, 52, 737-783. http://dx.doi.org/10.1111/j.1540-6261.1997.tb04820.x

Short, H., Zhang, H., \& Keasey, K. (2002). The link between dividend policy and institutional ownership. Journal of Corporate Finance, 8, 105-122. http://dx.doi.org/10.1016/S0929-1199(01)00030-X

Smith, R. J., \& Blundell, R. W. (1986). An exogeneity test for a simultaneous equation Tobit model with an application to labor supply. Econometrica, 54, 679-685. http://dx.doi.org/10.2307/1911314

Thanatawee, Y. (2011). Life-cycle theory and free cash flow hypothesis: Evidence from dividend policy in Thailand. International Journal of Financial Research, 2, 52-60. http://dx.doi.org/10.5430/ijfr.v2n2p52

Truong, T., \& Heaney, R. (2007). Largest shareholder and dividend policy around the world. The Quarterly Review of Economics and Finance, 47, 667-687. http://dx.doi.org/10.1016/j.qref.2007.09.002

Wiwattanakantang, Y. (2000). Controlling shareholders and corporate value: Evidence from Thailand. Pacific-Basin Finance Journal, 9, 323-362. http://dx.doi.org/10.1016/S0927-538X(01)00022-1

Wooldridge, J. M. (2010). Econometric analysis of cross section and panel data (2nd ed.). Massachusetts: MIT Press. 


\section{Notes}

Note 1. According to definition of the Stock Exchange of Thailand (SET), an investor holding at least $0.5 \%$ of total shares outstanding is considered a major shareholder.

Note 2. Alternatively, ownership concentration is measured by logarithm of the Herfindahl Hirschman Index (HHI), which is the sum of squared percentage of shares held by the five largest investors. However, the results are qualitatively the same.

Note 3. Harada and Nguyen (2011) also employ firm age as an instrumental variable in their study of ownership concentration and dividend policy in Japan.

Note 4. Additionally, AGE is not found to be related to dependent variable, DPR, suggesting that AGE in an appropriate instrumental variable. The result is not reported here but available upon request. 